\title{
PENGGUNAAN KINETIN PADA CABAI MERAH SEGAR TERHADAP MUTU ORGANOLEPTIK SELAMA PENYIMPANAN DENGAN KEMASAN BERBEDA
}

\author{
Edo Saputra \\ Dosen Jurusan Teknologi Pertanian, Fakultas Pertanian, Universitas Riau \\ email: edo.saputra@lecturer.unri.ac.id
}

\begin{abstract}
ABSTRAK
Kinetin (6-furfurylaminopurine) merupakan zat pengatur tumbuh pada tanaman golongan sitokinin yang berfungsi sebagai hormon penghambat proses penuaan sehingga dapat mempertahankan kesegaran dan warna produk pertanian. Aplikasi penggunaan kinetin dapat dilakukan pada penyimpanan cabai merah dengan kemasan yang berbeda pada suhu dingin dan suhu ruang. Penelitian ini bertujuan untuk mengkaji penggunaan kinetin terhadap mutu organoleptik cabai merah segar dengan tingkat kematangan 50-75\% selama penyimpanan. Penelitian ini menggunakan metode eksperimen dengan Rancangan Acak Lengkap Faktorial $\mathrm{A} \times \mathrm{B}$ dengan perlakuan jenis kemasan dan suhu penyimpanan. Jenis kemasan yang digunakan adalah kemasan PP, LDPE, dan tanpa kemasan, sedangkan suhu penyimpanan yaitu suhu dingin dan suhu ruang. Parameter organoleptik yang diamati meliputi warna, aroma, dan kekerasan cabai merah dengan tingkat kematangan 50-75\% yang telah direndam dalam larutan kinetin kemudian disimpan menggunakan kemasan berbeda pada suhu dingin dan suhu ruang. Hasil penelitian terbaik yang didapatkan adalah uji organoleptik kekerasan cabai merah merupakan parameter mutu terbaik selama penyimpanan dengan menggunakan kemasan PP yang disimpan pada suhu $8^{\circ} \mathrm{C}$.

Kata kunci- cabai merah; kemasan; kinetin; mutu organoleptik
\end{abstract}

\section{PENDAHULUAN}

Kinetin (6-furfurylaminopurine) merupakan zat pengatur tumbuh golongan sitokinin yang banyak digunakan dalam kultur jaringan tanaman. Kinetin merupakan sitokinin yang paling potensial digunakan pada pertumbuhan tunas pada tanaman kehutanan (Putriana et al., 2019). Sugiyono et al., (2009) menambahkan bahwa sitokinin merupakan hormon penghambat proses penuaan sehingga dapat mempertahankan kesegaran dan warna dari produk pertanian. Produk pertanian dengan nilai jual yang tinggi perlu dilakukan pemberian kinetin agar dapat mempertahankan kesegaran dan memperpanjang umur simpannya, salah satu produk pertanian tersebut adalah cabai merah.

Cabai merah (Capsicum annuum L.) merupakan produk hortikultura yang memiliki nilai jual yang tinggi dan sangat berpotensi untuk dibudidayakan karena termasuk salah satu dari sembilan kebutuhan pokok masyarakat. Selain berguna untuk penyedap masakan, cabai merah juga memiliki banyak kandungan gizi. Kebutuhan masyarakat untuk cabai merah cenderung mengalami peningkatan setiap tahunnya. Salah satu provinsi penghasil cabai merah di Indonesia adalah Sumatera Barat. Produksi cabai merah besar di Sumatera Barat pada tahun 2015 sampai tahun 2019 terus mengalami peningkatan. Produksi cabai besar tahun 2015 sebesar 63.402 ton, tahun 2016 sebesar 68.224 ton, tahun 2017 sebesar 95.489 ton, tahun 2018 sebesar 106.061 ton, dan tahun 2019 sebesar 139.994 ton (BPS, 2019).

Cabai merah termasuk produk non klimaterik yang mudah rusak selama penyimpanan dalam jangka waktu yang lama. Hal ini disebabkan oleh aktivitas respirasi dan transpirasi yang masih berlangsung selama penyimpanan. Oleh karena itu, cabai merah perlu penanganan pasca panen yang baik dan tepat sehingga dapat memperpanjang umur simpan serta mengatasi masalah penurunan mutu. Penanganan pasca panen yang dilakukan misalnya penyimpanan dengan suhu dingin, penggunaan kemasan serta menggunakan aplikasi hormon tanaman seperti kinetin. Sudaro (2000) menyatakan bahwa penyimpanan cabai merah yang sudah matang pada suhu ruang memiliki umur simpan sampai 5 hari penyimpanan sedangkan pada suhu kurang dari $10{ }^{\circ} \mathrm{C}$ memiliki umur simpan selama 10 hari penyimpanan. Lamona et al., (2015) menyatakan bahwa penyimpanan cabai merah keriting dengan kemasan polypropylene $(\mathrm{PP})$ pada suhu $10{ }^{\circ} \mathrm{C}$ dapat mempertahankan umur simpan mencapai 29 hari. Iswari et al. (2011) menyatakan bahwa penggunaan kinetin 15 ppm dapat mempertahankan kesegaran cabai merah selama 15 hari penyimpanan pada suhu ruang. Saputra et al., (2016) menambahkan 
penyimpanan cabai merah dengan penambahan kinetin pada cabai dengan tingkat kematangan 5075\% dapat bertahan selama 26 hari penyimpanan pada suhu ruang tanpa menggunakan kemasan.

Dalam penentuan masa simpan cabai merah dapat dilakukan berdasarkan pengukuran secara objektif yaitu dengan menggunakan alat serta pengukuran secara subjektif yaitu pengukuran dengan uji organoleptik. Uji organoleptik merupakan uji yang didasarkan pada proses penginderaan. Bagian organ tubuh yang berperan dalam penginderaan adalah indera penglihatan (mata), indera pembau (hidung), dan indera perabaan atau sentuhan. Parameter yang menjadi tolak ukur konsumen dalam memilih cabai merah adalah warna, aroma dan kekerasan. Hal ini merupakan penilaian pertama secara visual yang dilakukan konsumen dalam memilih produk. Puspitasari dan Putra (2019) menyatakan bahwa tidak terdapat perbedaan mutu cabai merah segar berdasarkan tingkat kesegaran, warna, tekstur, dan hedonik pada suhu ruang dengan jenis kemasan yang berbeda tetapi terdapat perbedaan mutu cabai merah besar segar berdasarkan aroma pada suhu ruang dengan jenis kemasan yang berbeda. Penelitian ini bertujuan untuk mengkaji penggunaan kinetin pada cabai merah segar terhadap mutu organoleptik selama penyimpanan dengan kemasan berbeda.

\section{METODOLOGI PENELITIAN}

\section{A. Bahan dan Alat}

Bahan yang digunakan dalam penelitian ini adalah cabai merah segar varietas lokal dengan tingkat kematangan 50-75\% saat buahnya berwarna cokelat sampai merah $3 / 4$ bagian. Jenis kemasan yang digunakan adalah plastik polypropylene (PP), plastik Low Density Polyethylene (LDPE), styrofoam, dan larutan kinetin dengan konsentrasi $15 \mathrm{ppm}$. Alat yang digunakan adalah kulkas (refrigerator), timbangan digital, thermometer, dan rak penyimpanan.

\section{B. Rancangan Penelitian}

Penelitian ini menggunakan model rancangan yaitu Rancangan Acak Lengkap (RAL) $A \times B$ Faktorial. Faktor $\mathrm{A}$ : jenis kemasan $\left(\mathrm{A}_{0}=\right.$ tanpa kemasan; $\mathrm{A}_{1}=$ kemasan polypropylene $(\mathrm{PP}) ; \mathrm{A}_{2}=$ kemasan low density polyethylene (LDPE)). Faktor $\mathrm{B}$ : suhu penyimpanan $\left(\mathrm{B}_{1}=\right.$ suhu $8{ }^{\circ} \mathrm{C}$ dan $\mathrm{B}_{2}=$ suhu ruang). Kombinasi perlakuan yaitu: $\mathrm{A}_{0} \mathrm{~B}_{1}$ (tanpa kemasan suhu $8{ }^{\circ} \mathrm{C}$ ), $\mathrm{A}_{1} \mathrm{~B}_{1}$ (kemasan PP suhu $8{ }^{\circ} \mathrm{C}$ ), $\mathrm{A}_{2} \mathrm{~B}$ (kemasan LDPE suhu $8{ }^{\circ} \mathrm{C}$ ), $\mathrm{A}_{0} \mathrm{~B}_{2}$ (tanpa kemasan suhu ruang), $\mathrm{A}_{1} \mathrm{~B}_{2}$ (kemasan PP suhu ruang), dan $\mathrm{A}_{2} \mathrm{~B}_{2}$ (kemasan LDPE suhu ruang).

\section{Prosedur Percobaan}

Penelitian menggunakan metode eksperimen dengan tahapan persiapan bahan, penyiapan kemasan, pembuatan larutan kinetin dan penyimpanan cabai merah dengan tingkat kematangan 50$75 \%$ pada suhu ruang dan suhu dingin. Dalam melakukan penelitian, cabai dengan tingkat kematangan 50-75\% diberikan perlakuan kinetin dengan konsentrasi 15 ppm direndam selama 20 menit. Cabai merah dengan tingkat kematangan 50-75\% yang sudah direndam, kemudian dikeringanginkan lalu dikemas menggunakan kemasan yang berbeda yaitu kemasan PP dan LDPE. Cabai merah dengan tingkat kematangan 50-75\% yang sudah dikemas disimpan dalam kulkas dan rak penyimpanan (suhu ruang). Pengambilan data uji organoleptik dilakukan setiap dua hari sekali selama 30 hari penyimpanan. Ulangan dalam penelitian ini sebanyak 3 kali ulangan.

\section{Pengamatan}

Parameter pengamatan yang diamati dalam penelitian ini adalah uji organoleptik yang meliputi warna, aroma dan kekerasan pada cabai dengan tingkat kematangan 50-75\% selama penyimpanan 30 hari menggunaan kemasan yang berbeda pada suhu dingin dan suhu ruang.

\section{E. Analisis Data}

Uji organoleptik pada cabai merah dengan tingkat kematangan 50-75\% dilakukan secara hedonik. Uji hedonik bertujuan untuk mengetahui tingkat kesukaan panelis terhadap warna, aroma, dan kekerasan cabai merah dengan tingkat kematangan 50-75\% pada masing-masing perlakuan. Panelis diminta untuk memberikan gambaran tentang sampel yang diamati sesuai dengan skala yang telah ditetapkan. Panelis yang dibutuhkan merupakan panelis semi terlatih sebanyak 20 orang. Uji 
hedonik atau kesukaan menggunakan metode skoring dengan skor $1=$ sangat tidak suka, $2=$ tidak suka, $3=$ suka, $4=$ lebih suka, dan $5=$ sangat suka.

\section{HASIL DAN PEMBAHASAN}

Uji organoleptik merupakan salah satu cara yang digunakan untuk mengetahui penilaian panelis terhadap tingkat kesukaan berdasarkan perubahan-perubahan yang terjadi pada cabai merah dengan tingkat kematangan $50-75 \%$ yang berbeda selama penyimpanan dengan kemasan yang berbeda setelah diberikan perlakuan kinetin $15 \mathrm{ppm}$. Uji organoleptik yang dilakukan berdasarkan pengujian sensori menggunakan alat indera yang digunakan. Panelis diminta melakukan pengujian terhadap warna, aroma, dan kekerasan cabai dengan tingkat kematangan $50-75 \%$ yang berbeda selama penyimpanan.

\section{A. Warna}

Pengaruh kombinasi kemasan dan suhu terhadap uji organoleptik warna cabai tingkat kematangan 50-75\% selama penyimpanan dapat dilihat pada Gambar 1, sedangkan rata-rata uji organoleptik warna cabai merah dengan tingkat kematangan 50-75\% dapat dilihat pada Gambar 2 . Gambar 1 ditampilkan grafik uji organoleptik warna cabai dengan tingkat kematangan 50-75\% dengan kemasan PP, LDPE, dan tanpa menggunakan kemasan pada suhu dingin dan suhu ruang.

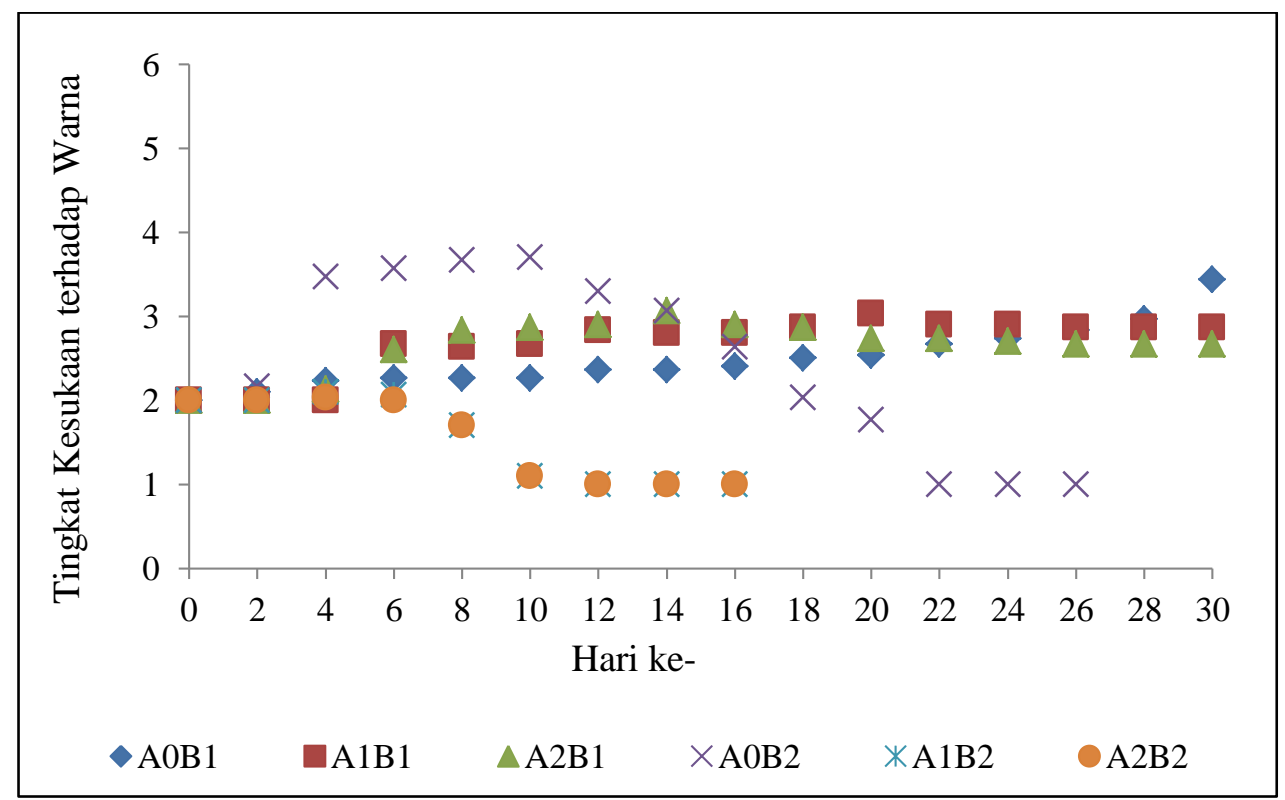

Gambar 1. Uji Organoleptik Warna Cabai Tingkat Kematangan 50-75\%

pada Kemasan dan Suhu yang Berbeda

Gambar 1 merupakan uji organoleptik warna cabai tingkat kematangan 50-75\% selama penyimpanan dingin. Berdasarkan penilaian panelis selama penyimpanan cabai tingkat kematangan 50-75\% mengalami kenaikan dan penurunan uji organoleptik. Selama penyimpanan pada suhu dingin, cabai yang disimpan pada kemasan PP dan LDPE memberikan tingkat kesukaan yaitu "suka" mulai pada hari ke-6 sampai penyimpanan ke-30. Hal ini menandakan bahwa warna cabai mengalami kenaikan dengan perubahan warna menjadi merah selama penyimpanan, namun tidak mengalami kemunduran perubahan warna. Hal ini dikarena cabai merah termasuk golongan buah non klimaterik, dimana sifat dari buah non klimaterik yaitu setelah melalui fase pemasakan kemudian menuju fase pembusukan (senescence). Sejalan dengan perubahan warna, dapat dibuktikan bahwa penggunaan kinetin pada cabai merah kemudian disimpan dengan kemasan PP dan LDPE pada suhu dingin dapat mempertahankan warna cabai selama penyimpanan sehingga disukai oleh panelis. Mandana et al., (2012) menyebutkan bahwa penyimpanan cabai merah dengan perlakuan klorin dan kemasan PP terperforasi 3\% sangat baik digunakan untuk mempertahankan warna buah cabai. Nurdjannah et al., (2014) menambahkan faktor kemasan dan suhu tidak terlalu berpengaruh nyata terhadap nilai warna 
cabai, hal ini disebabkan oleh karakteristik cabai merah yang termasuk buah non klimaterik. Buah non klimaterik biasanya tidak terlihat nyata perubahan yang terjadi pada fase pemasakan karena proses respirasi pada produk yang berjalan lambat selama penyimpanan, dalam hal ini termasuk juga proses perombakan pigmen warna pada kulit cabai merah.

Penyimpanan cabai tingkat kematangan 50-75\% dengan kemasan PP dan LDPE pada suhu ruang hanya mengalami kemunduran tingkat kesukaan yaitu "tidak suka" karena cabai tidak mengalami perkembangan warna selama penyimpanan suhu ruang tetapi mengalami kebusukan. Penyimpanan tanpa menggunakan kemasan mengalami peningkatan tingkat kesukaan sampai batas "suka" pada hari ke-16, dan kemudian mengalami kemunduran dari hari ke-18 sampai hari ke-26 penyimpanan pada suhu ruang. Hal ini disebabkan karena cabai merah mengalami proses respirasi selama penyimpanan. Respirasi cabai merah dengan kemasan PP dan LDPE tergolong rendah karena dapat dipertahankan sampai penyimpanan hari ke-12 pada suhu ruang, sedangkan tanpa kemasan dapat dipertahankan sampai hari ke- 26. Rendahnya intensitas pembusukan pada cabai merah dikarenakan penggunaan kemasan PP yang dapat menahan keluar masuknya gas sehingga laju respirasi menjadi menurun, mengurangi pertumbuhan mikroba serta mengurangi kerusakan yang disebabkan oleh enzim sehingga dapat memperpanjang umur simpan. Selain itu, kemasan PP merupakan jenis kemasan dengan nilai permeabilitas yang sangat rendah terhadap udara dan air yang artinya kemasan ini memiliki daya tembus terhadap udara dan air dari kemasan sangat rendah terhadap kemasan yang digunakan tersebut (Mandana et al., 2012). Rochayat dan Munika (2015) menambahkan perlakuan cabai merah kematangan 60-70\% dengan wadah styrofoam yang dikemas dengan clear polyethylene merupakan perlakuan terbaik yang dapat menunda perubahan warna menjadi merah $100 \%$. Biasanya proses pematangan buah dihubungkan dengan rangkaian perubahan yang meliputi warna, aroma, konsistensi dan flavor (rasa dan bau). Terkait warna pada buah cabai merah, biasanya semakin tinggi tingkat (indeks) kematangan cabai merah, maka akan semakin tinggi pula perubahan warna pada buah tersebut akan terjadi.

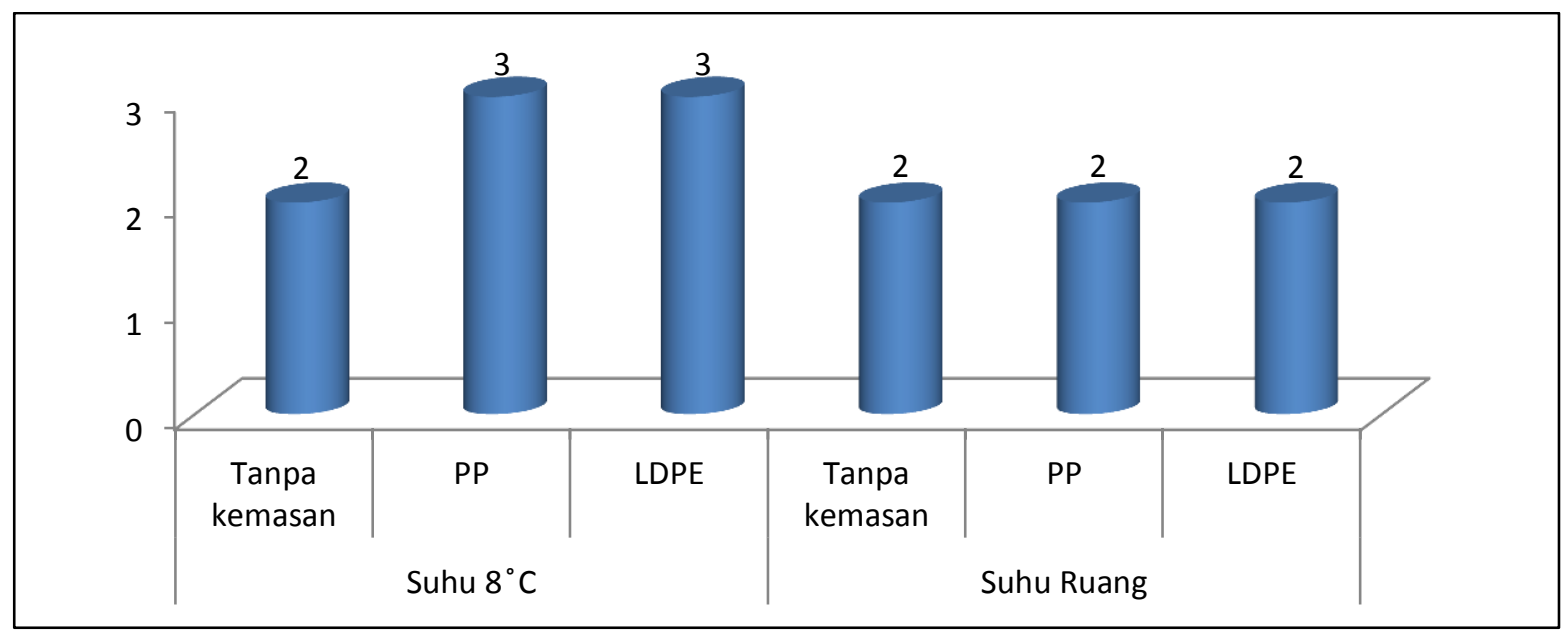

Gambar 2. Rata-rata Uji Organoleptik Warna Cabai Tingkat Kematangan 50-75\% pada Kemasan dan Suhu yang Berbeda

Berdasarkam Gambar 2 dapat dilihat bahwa rata-rata penilaian panelis terhadap warna cabai tingkat kematangan 50-75\% pada suhu dingin tanpa kemasan adalah "tidak suka". Hal ini disebabkan oleh tidak terjadinya perubahan warna cokelat kemerahan selama penyimpanan. Penilaian panelis pada penggunaan kemasan PP dan LDPE adalah "suka". Hal ini disebabkan selama penyimpanan cabai merah dengan tingkat kematangan 50-75\% mengalami perubahan warna dari cokelat kemerahan menjadi merah dan selama penyimpanan masih mempertahankan warna merah pada cabai. Rata-rata penilaian panelis terhadap warna cabai tingkat kematangan 50-75\% pada suhu ruang tanpa kemasan, kemasan PP, dan kemasan LDPE adalah "tidak suka". Hal ini disebabkan karena penyimpanan cabai merah tingkat kematangan 50-75\% pada suhu ruang mengalami kerusakan. Cabai merah yang disimpan tanpa kemasan mengalami perubahan warna menjadi merah kehitaman, sedangkan cabai merah yang disimpan dengan kemasan PP dan LDPE mengalami perubahan warna menjadi kecoklatan. Penentuan mutu warna pada bahan hasil pertanian umumnya tergantung pada penampilan 
warna terlebih dahulu yang dinilai oleh konsumen. Senyawa penyusun yang terdapat pada cabai merah adalah karatenoid yang terdiri dari karoten, kapsorubin, kapsantin, serta zeaxanthin (Nursari et al., 2016). Nurdjannah et al., (2014) menambahkan perubahan warna cabai merupakan perubahan yang paling terlihat selama proses pematangan buah karena terjadinya sintesis pigmen seperti karotenoid dan flavonoid, disamping itu juga terjadi perombakan klorofil. Warna pada cabai merah dikendalikan oleh beberapa senyawa karotenoid seperti capsanthin, capsorubin, dan xanthophylls untuk warna merah, sedangkan warna kuning orange oleh senyawa $\beta$-karoten dan zeaxanthin.

\section{B. Aroma}

Pengaruh kombinasi kemasan dan suhu terhadap aroma cabai tingkat kematangan 50-75\% selama penyimpanan dapat dilihat pada Gambar 3, sedangkan rata-rata uji organoleptik aroma cabai merah dengan tingkat kematangan 50-75\% dapat dilihat pada Gambar 4. Gambar 3 ditampilkan grafik uji organoleptik aroma cabai dengan tingkat kematangan 50-75\% dengan kemasan PP, LDPE, dan tanpa menggunakan kemasan pada suhu dingin dan suhu ruang.

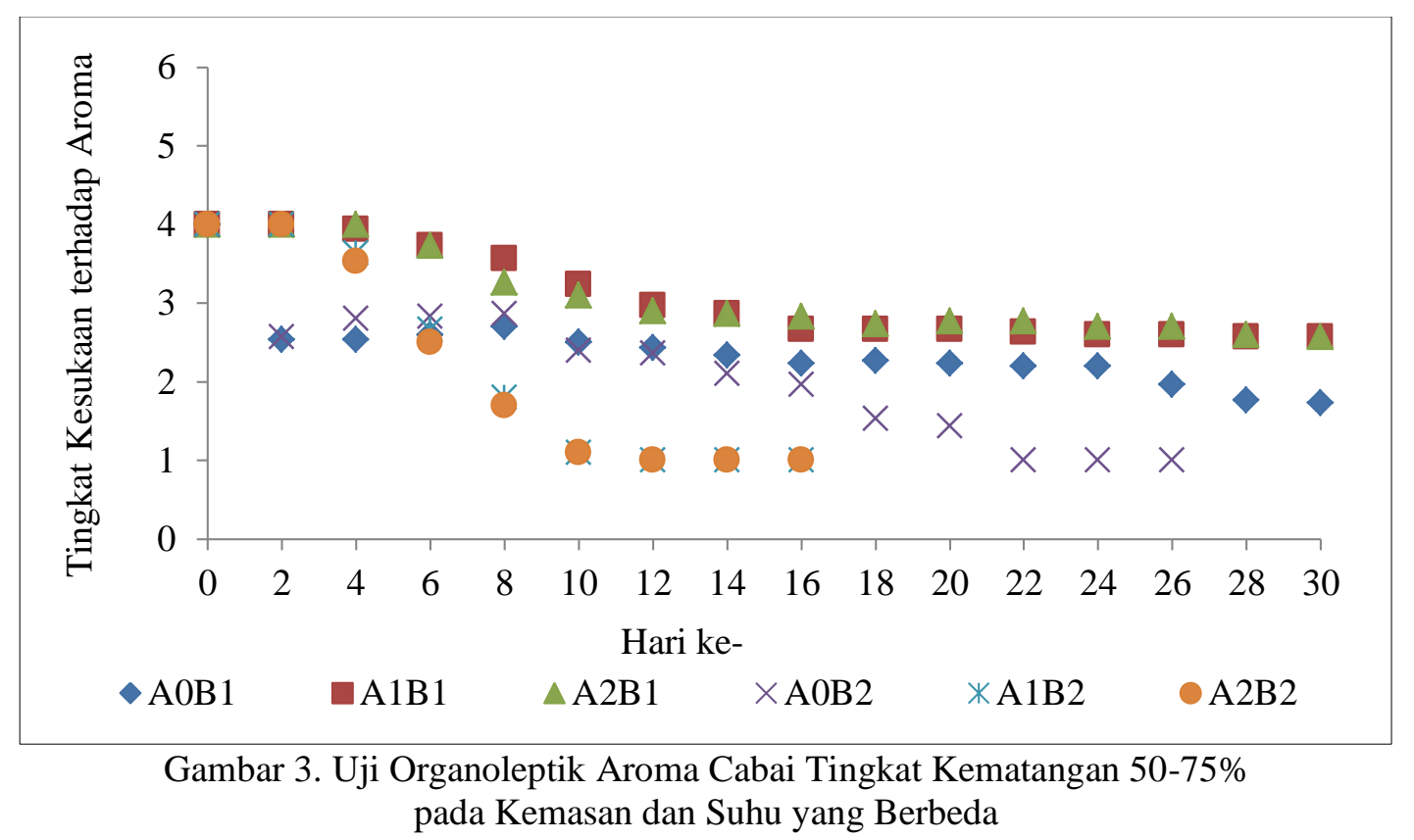

Gambar 3 merupakan penilaian aroma cabai tingkat kematangan 50-75\% yang disimpan pada kemasan dan suhu yang berbeda. Berdasarkan Gambar 3 dapat dilihat bahwa selama penyimpanan, aroma cabai tingkat kematangan 50-75\% mengalami penurunan selama penyimpanan dengan kemasan PP, LDPE, dan tanpa menggunakan kemasan. Penyimpanan cabai tingkat kematangan 50$75 \%$ pada suhu dingin menggunakan kemasan PP dan LDPE yang digunakan dalam menyimpan cabai tingkat kematangan 50-75\% dapat mempertahankan aroma sampai hari ke-30 dan tanpa menggunakan kemasan sampai hari ke-10 dengan penilaian panelis adalah "suka". Penyimpanan cabai tingkat kematangan 50-75\% pada suhu ruang dengan kemasan PP dan LDPE dapat mempertahankan aroma sampai hari ke-6 serta tanpa menggunakan kemasan sampai hari ke-8 penyimpanan dengan penilaian panelis adalah "suka". Penurunan penilaian aroma cabai merah pada penyimpanan suhu dingin dan suhu ruang diduga karena tumbuhnya kapang pada tangkai cabai merah. Selain itu, penggunaan kemasan juga menyebabkan bertambahnya $\mathrm{CO}_{2}$ dalam kemasan dan terjadi pengurangan $\mathrm{O}_{2}$. Hal ini sejalan dengan hasil penelitian Puspitasari dan Putra (2019) yang mendapatkan hasil bahwa terdapat perbedaan mutu aroma cabai merah besar yang disimpan menggunakan kemasan berbeda pada suhu ruang. Hal ini disebabkan oleh tumbuhnya kapang pada permukaan tangkai cabai merah besar selama penyimpanan. Selain itu, terjadi penumpukan $\mathrm{CO}_{2}$ dan penyusutan $\mathrm{O}_{2}$ yang kemungkinan timbulnya rasa dan aroma yang tidak diinginkan karena kemasan yang digunakan tertutup (rapat) sehingga oksigen bebas akan terpakai dalam waktu singkat, respirasi menjadi anaerob dan terbentuklah zat-zat menguap seperti alkohol dan $\mathrm{CO}_{2}$. 
Berdasarkan Gambar 4 dapat dilihat bahwa rata-rata penilaian panelis terhadap aroma cabai tingkat kematangan 50-75\% pada suhu dingin tanpa kemasan adalah "tidak suka".. Penilaian panelis pada penggunaan kemasan PP dan LDPE adalah "suka". Rata-rata penilaian panelis terhadap aromacabai tingkat kematangan 50-75\% pada suhu ruang tanpa kemasan, kemasan PP, dan kemasan LDPE adalah "tidak suka". Hal ini disebabkan oleh adanya senyawa volatil yang mudah menguap yang terdapat pada cabai merah seperti capsaicin, alkohol, keton dan lainnya. Selain itu senyawa volatil yang dapat mempengaruhi aroma cabai merah selama penyimpanan adalah asam, keton, aldehyde, ester, piroline, furan, dan senyawa hidrokarbon (Kalsum, 2018). Puspitasari dan Putra (2019) menambahkan cabai merah besar akan mengalami penyimpangan aroma akibat terjadinya oksidasi selama penyimpanan. Hal ini kebanyakan dapat terjadi pada sayur dan buah yang memiliki kandungan lemak sedikit, tetapi oksidasi asam lemak tak jenuh akan menghasilkan hidroperoksida kemudian bereaksi lebih lanjut dengan polimerisasi, dehidrasi atau oksidasi yang menghasilkan keton, aldehid, serta asam yang dapat menyebabkan ketengikan dan aroma yang tidak sedap.

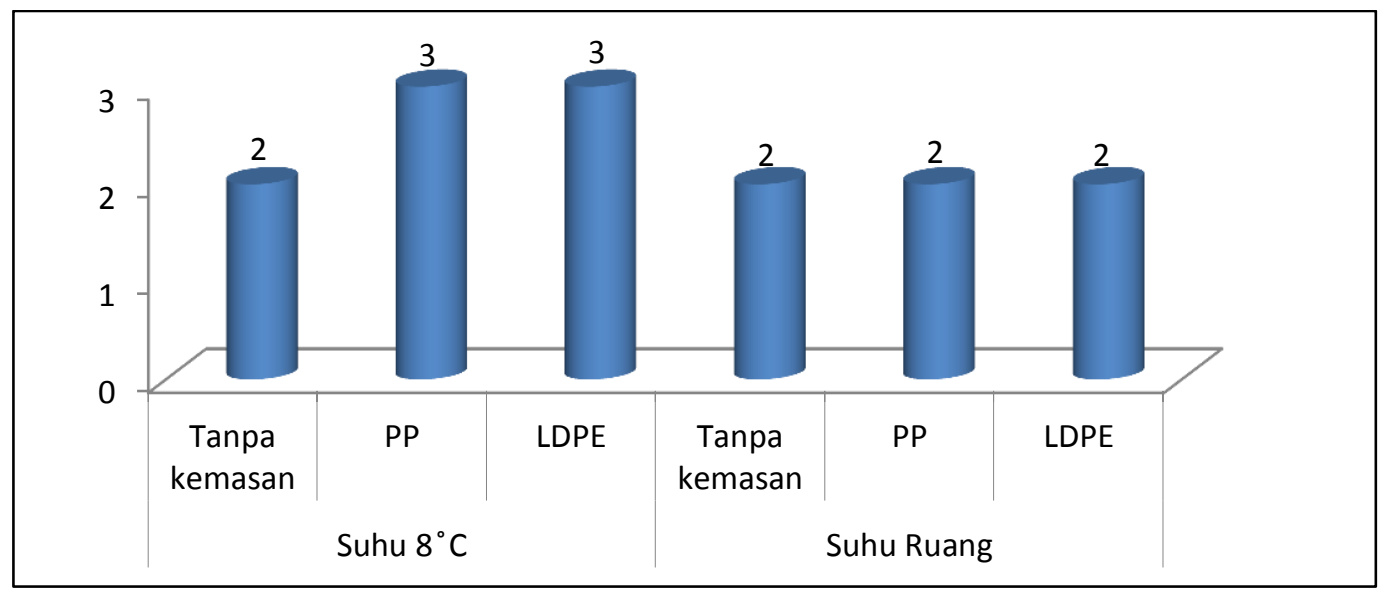

Gambar 4. Rata-rata Uji Organoleptik Aroma Cabai Tingkat Kematangan 50-75\% pada Kemasan dan Suhu yang Berbeda

\section{Kekerasan}

Pengaruh kombinasi kemasan dan suhu terhadap kekerasan cabai tingkat kematangan 50-75\% selama penyimpanan dapat dilihat pada Gambar 5, sedangkan rata-rata uji organoleptik kekerasan cabai merah dengan tingkat kematangan 50-75\% dapat dilihat pada Gambar 6. Gambar 5 ditampilkan grafik uji organoleptik kekerasan cabai dengan tingkat kematangan $50 \%$ dengan kemasan PP, LDPE, dan tanpa menggunakan kemasan pada suhu dingin dan suhu ruang.

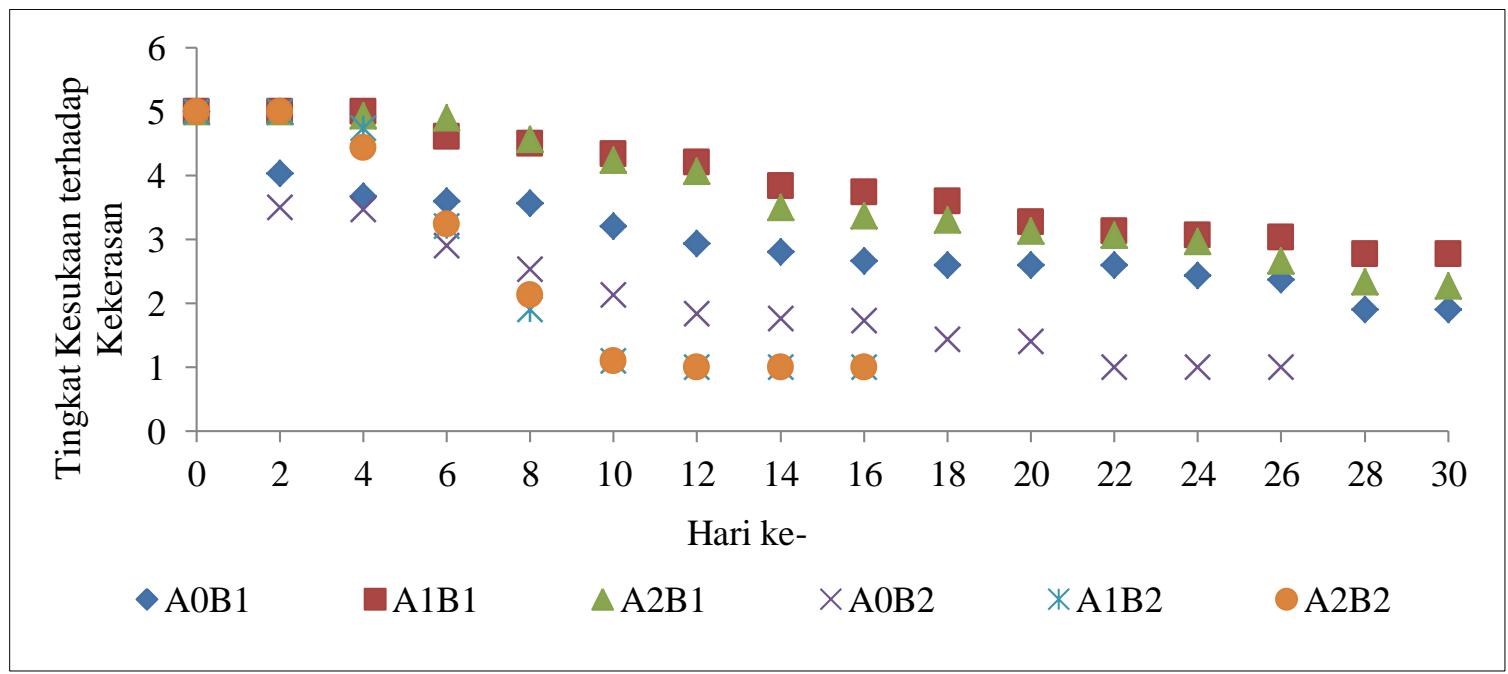

Gambar 5. Uji Organoleptik Kekerasan Cabai Tingkat Kematangan 50-75\% pada Kemasan dan Suhu yang Berbeda 
Gambar 5 merupakan penilaian kekerasan cabai tingkat kematangan 50-75\% yang disimpan pada kemasan dan suhu yang berbeda. Berdasarkan Gambar 5 dapat dilihat bahwa selama penyimpanan, kekerasan cabai tingkat kematangan 50-75\% mengalami penurunan selama penyimpanan dengan kemasan PP, LDPE, dan tanpa menggunakan kemasan. Penyimpanan cabai tingkat kematangan 50-75\% pada suhu dingin menggunakan kemasan PP dapat mempertahankan kekerasan cabai sampai hari ke-30, kemasan LDPE dapat mempertahankan kekerasan sampai hari ke26 dan tanpa menggunakan kemasan sampai hari ke-22 dengan penilaian panelis adalah "suka". Penyimpanan cabai tingkat kematangan 50-75\% pada suhu ruang dengan kemasan PP dan LDPE dapat mempertahankan kekerasan sampai hari ke-6 dan tanpa menggunakan kemasan sampai hari ke8 penyimpanan dengan penilaian panelis adalah "suka". Nur (2009) mengemukakan tentang aktifitas mikroorganisme yang mampu mendegradasi protein menjadi senyawa yang lebih sederhana dan menyebabkan kemampuan protein dalam mengikat air menjadi menurun sehingga menyebabkan tekstur menjadi lunak. Nurdjannah et al., (2014) menambahkan bahwa perubahan tekstur produk yang semula keras menjadi lunak disebabkan karena kehilangan air yang menjadikan komposisi dinding sel berubah sehingga menyebkan menurunnya tekanan turgor sel dan kekerasan buah juga menurun. Selain itu, juga terjadi perubahan secara kimia pada dinding sel yang tersusun dari senyawa-senyawa komplek dari golongan karbohidrat struktural seperti selulosa, hemiselulosa, pektin, dan lignin.

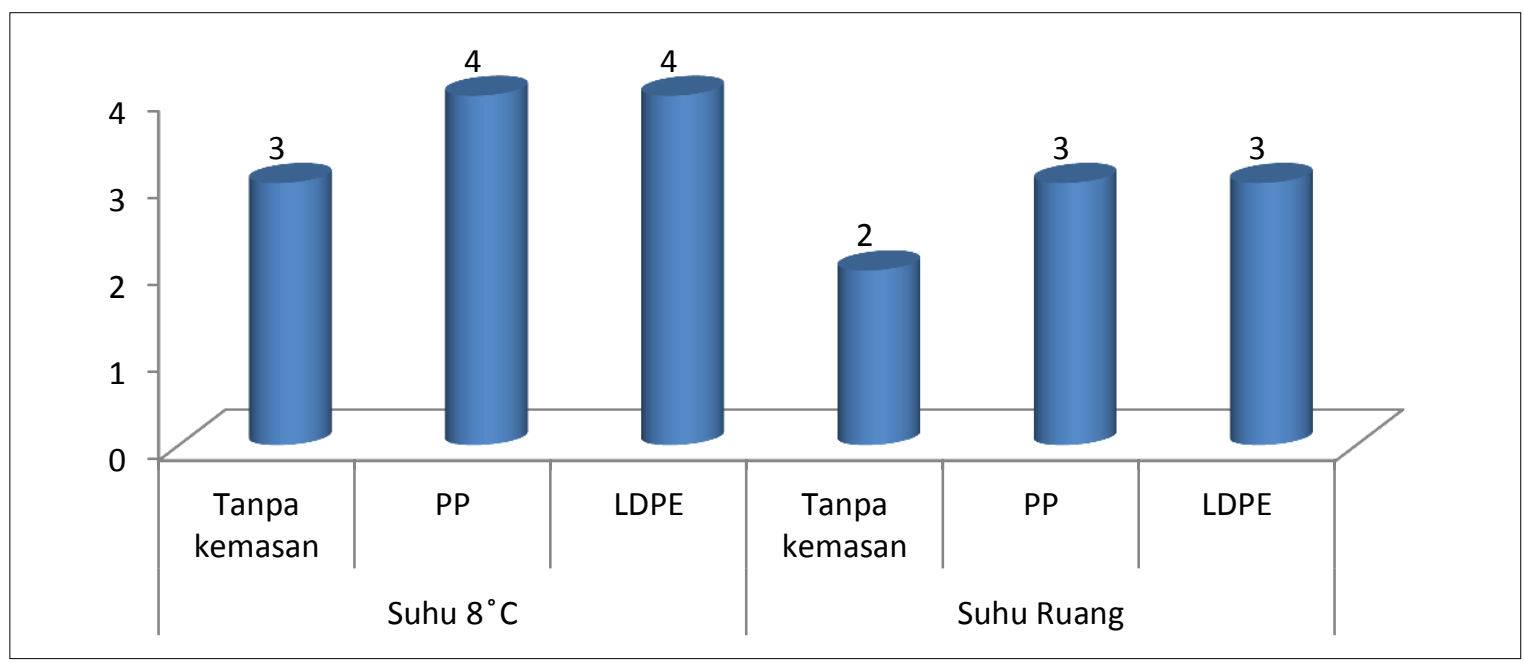

Gambar 6. Rata-rata Uji Organoleptik Kekerasan Cabai Tingkat Kematangan 50-75\% pada Kemasan dan Suhu yang Berbeda

Berdasarkan Gambar 6 dapat dilihat bahwa rata-rata penilaian panelis terhadap kekerasan cabai tingkat kematangan 50-75\% pada suhu dingin tanpa kemasan adalah "suka". Penilaian panelis pada penggunaan kemasan PP dan LDPE adalah "lebih suka". Hal ini disebabkan selama penyimpanan cabai merah dengan tingkat kematangan 50-75\% menggunakan kemasan PP, LDPE, dan tanpa kemasan masih mempertahankan kekerasan pada cabai. Rata-rata penilaian panelis terhadap kekerasan cabai tingkat kematangan 50-75\% pada suhu ruang adalah "tidak suka". Penilaian panelis pada penggunaan kemasan PP dan kemasan LDPE adalah "suka". Hal ini disebabkan karena penyimpanan cabai merah tingkat kematangan 50-75\% pada suhu ruang tanpa kemasan mengalami kerusakan yang diakibatkan oleh kehilangan air akibat respirasi dan transpirasi. Cabai merah yang disimpan dengan kemasan PP dan LDPE memiliki kekerasan yang disukai oleh panelis disebabkan oleh penggunaan kemasan yang mampu mempertahankan kehilangan air selama penyimpanan. Kekerasan cabai merah berhubungan dengan tingkat kesegaran cabai merah selama penyimpanan. Mandana et al. (2012) menjelaskan tentang penggunaan kemasan PP mempunyai sifat permeabilitas tinggi yang dapat mengatur laju penyerapan atmosfer sehingga memperlambat laju kemunduran produk dan dapat mempertahankan kesegaran buah lebih lama. Nurdjannah et al., (2014) menambahkan cabai rawit putih selama penyimpanan menjadi lunak dan keriput yang disebabkan oleh oksidasi pektin, apabila cabai rawit mengalami pematangan maka pektin tidak mampu mengikat air pada buah cabai sehingga air yang keluar semakin besar dan mengakibatkan tekstur menjadi melunak serta keriput. 


\section{KESIMPULAN}

Berdasarkan penelitian yang telah dilakukan dapat disimpulkan bahwa penyimpanan cabai merah tingkat kematangan 50-75\% yang telah direndam dalam larutan kinetin 15 ppm adalah uji organoleptik kekerasan cabai merah merupakan parameter mutu terbaik selama penyimpanan dengan menggunakan kemasan PP yang disimpan pada suhu $8^{\circ} \mathrm{C}$.

\section{DAFTAR PUSTAKA}

BPS. 2019. Produktivitas Cabai Besar Menurut Provinsi, Tahun 2015-2019. 2019: 2019.

Iswari, K., A. Syufri, A. Waita dan Harmaini. 2011. Cara Benar Menyimpan Cabe Merah. Peneliti dan Penyuluh pada BPTP Sumbar: ePetani.

Kalsum, U. 2018. Studi Pengaruh Tangkai Buah Terhadap Mutu Cabai Rawit (Capsicum frutescens L.) Selama Penyimpanan. Interciencia. 489(20): 313-335.

Lamona, A., Y. A. Purwanto, dan S. Sutrisno. 2015. Effect of Different Packaging and Low Temperature Storage on the Quality Changes of Fresh Red Curly Chili. Jurnal Keteknikan Pertanian. 03(2): 1-8.

Mandana, G. O., I. M. S. Utama, dan N. L. Yulianti. 2012. Pengaruh Larutan Disinfektan dan Pengemasan Atmosfer Termodifikasi Menggunakan Film Plastik Terperforasi Terhadap Susut Bobot dan Mutu Buah Cabai Merah Besar (Capsicum annuum L.) Selama Penyimpnan. BETA (Biosistem dan Teknik Pertanian). (1): 1-10.

Nur, M. 2009. Pengaruh Cara Pengemasan, Jenis Bahan Pengemas dan Lama Penyimpanan Terhadap Sifat Kimia, Mikrobiologi dan Organoleptik Sate Bandeng (Chanos Chanos). Jurnal Teknologi dan Industri Hasil Pertanian; Vol 14, No. 1. Lampung: Bandar Lampung.

Nurdjannah, R., Y. A. Purwanto, dan Sutrisno. 2014. Pengaruh Jenis Kemasan dan Suhu Penyimpanan Dingin Terhadap Mutu Fisik Cabai Merah. Jurnal Pascapanen. 1: 19-29.

Nursari, L. Karimuna, dan Tamrin. 2016. Pengaruh pH dan suhu pasteurisasi terhadap karakteristik kimia, organoleptik dan daya simpan sambal. Jurnal Sains Dan Teknologi Pangan. 1(2): 151158.

Puspitasari, D., dan D. D. Putra. 2019. Mutu Cabai Merah Besar Segar (capsicum annum 1.) Pada Suhu Ruang Dengan Jenis Pengemasan Yang Berbeda Selama Penyimpanan. KESMAS UWIGAMA: Jurnal Kesehatan Masyarakat. 5(1): 16.

Putriana, Gusmiaty, M. Restu, Musriati, dan N. Aida. 2019. Respon Kinetin Dan Tipe Eksplan Jabon Merah (Antocephalus macrophyllus (Roxb.) Havil) Secara In Vitro. Jurnal Biologi Makassar. 4(1): 48-57. Diambil dari https://jurnalmahasiswa.unesa.ac.id/index.php/lenterabio/article/view/14559/13212

Rochayat, Y., dan V. R. Munika. 2015. Respon kualitas dan ketahanan simpan cabai merah (Capsicum annuum L.) dengan penggunaan jenis bahan pengemas dan tingkat kematangan buah. Kultivasi. 14(1): 65-72.

Saputra, E., Santosa, dan Andasuryani. 2016. Aplikasi Kinetin Untuk Memperpanjang Umur Simpan Cabai Merah (Capsicum annuum L. ). Jurnal Teknologi Pertanian Andalas. 20(2).

Sudaro, Y. dan Dewi A.R. 2000. Pengeringan Cabai. Jakarta: Penebar Swadaya.

Sugiyono, Sutrisno, dan B. Dwiarsih. 2009. Pengaruh pelilinan buah manggis (Garcinia mangostana L.) selama penyimpanan. Seminar Nasional Gelar Teknologi PERTETA. 72-86. 